\title{
Perancangan Aplikasi Perhitungan dan Optimisasi Konstruksi Profil pada Midship Kapal Berdasar Rule Biro Klasifikasi Indonesia
}

\author{
Aditya Rachman, Totok Yulianto dan Dony Setyawan \\ Departemen Teknik Perkapalan, Fakultas Teknologi Kelautan, Institut Teknologi Sepuluh Nopember \\ (ITS) \\ e-mail: totoky@na.its.ac.id, dony@na.its.ac.id
}

\begin{abstract}
Abstrak-Perhitungan konstruksi kapal pada umumnya akan menghasilkan modulus penampang midship yang nilainya jauh diatas batas minimum. Kelebihan nilai ini berdasarkan peraturan bukanlah suatu masalah. Namun dari segi ekonomi akan dibutuhkan biaya lebih yang sebenarnya dapat dihemat. Salah satu cara untuk mengurangi perbandingan modulus penampang midship dengan batas minimum yaitu dengan melakukan optimisasi ukuran profil-profil. Perhitungan dan optimisasi konstruksi profil akan terbantu dengan menerapkan teknologi dalam prosesnya, seperti memanfaatkan aplikasi Solver dan pemrograman Visual Basic for Applications (VBA) dalam Excel. Dengan menggunakan pemrograman VBA pada Excel untuk otomatisasi perhitungan dan optimisasi, dapat diciptakan aplikasi untuk perhitungan konstruksi profil pada midship. Optimisasi menggunakan Solver dengan metode GRG Nonlinear menghasilkan perubahan nilai modulus penampang midship terhadap geladak dari $20.71 \%$ menjadi $19.55 \%$ terhadap batas minimal Biro Klasifikasi Indonesia (BKI). Untuk modulus penampang midship terhadap alas dari $\mathbf{5 1 . 9 2 \%}$ menjadi $\mathbf{5 1 . 4 3 \%}$ terhadap batas minimal BKI.
\end{abstract}

Kata Kunci-GRG nonlinear, konstruksi midship, modulus penampang, optimisasi, Visual Basic for Applications.

\section{PENDAHULUAN}

$\mathrm{P}$ ADA Departemen Teknik Perkapalan ITS telah dilakukan perancangan aplikasi perhitungan untuk konstruksi pada midship tanker. Dari aplikasi ini dihasilkan perhitungan modulus penampang profil serta perhitungan-perhitungan yang diperlukan, dimensi profil yang digunakan dan gambar penampang melintang midship [1]. Selain itu juga telah dilakukan perancangan aplikasi perhitungan untuk konstruksi pada ruang mesin tanker. Aplikasi ini juga menghasilkan dimensi profil yang digunakan beserta perhitungan yang terkait dan gambar penampang melintang ruang mesin [2].

Kedua studi ini melakukan perancangan aplikasi menggunakan Borland Delphi dan lebih mengarah pada edukasi untuk mahasiswa dalam mempelajari konstruksi kapal. Karena itu pada kedua studi ini lebih fokus dalam proses perhitungan terkait modulus penampang profil dan penggambaran penampang melintang midship atau ruang mesin. Pada studi [1] belum dilakukan pemeriksaan minimum midship modulus section dari hasil yang didapatkan. Kemudian tindakan apa yang harus dilakukan aplikasi jika hasil perhitungan tersebut tidak memenuhi batas minimum maupun memenuhi dengan perbedaan yang jauh.

Perhitungan konstruksi kapal pada umumnya akan menghasilkan modulus penampang midship dengan nilai diatas dari batas minimal. Kelebihan nilai ini berdasar peraturan memang diperbolehkan selama tidak dibawah batas minimal. Namun dari segi ekonomis kelebihan tersebut tidak baik, karena konstruksi lebih besar dan menyebabkan peningkatan berat serta membutuhkan yang biaya lebih besar. Padahal selama masih ada jarak antara nilai perhitungan modulus penampang midship dengan batas minimal, masih terdapat kemungkinan untuk menghemat pengeluaran.

Salah satu cara untuk mengurangi perbedaan modulus penampang midship dengan batas minimal yaitu dengan mengganti profil-profil pembujur ke ukuran yang lebih kecil. Namun cara ini bermasalah jika modulus penampang profilprofil tersebut dibawah batas minimum. Karena ada batasanbatasan ini, cara yang bisa digunakan untuk memenuhi kedua batas minimal tersebut yaitu dengan melakukan variasi ukuran pada profil yang telah dipilih berdasar batas minimal.

Proses perhitungan optimisasi profil-profil pada kapal memerlukan banyak waktu jika dilakukan secara manual oleh manusia. Karena itu pemanfaatan teknologi diperlukan untuk membantu proses perhitungan. Berbagai proses perhitungan pada umumnya banyak yang memanfaatkan teknologi spreadsheet seperti Microsoft Excel. Pada Excel terdapat aplikasi Solver untuk melakukan pencarian nilai optimal dan Visual Basic for Applications (VBA) sebagai bahasa pemrograman untuk otomatisasi. Dukungan Solver dan VBA pada Excel dapat dimanfaatkan untuk membantu melakukan perhitungan dan optimisasi konstruksi profil kapal.

Perancangan ini dilakukan untuk mengoptimisasi profilprofil agar modulus penampang midship mendekati batas minimum modulus penampang midship tanpa melanggar batas minimum modulus penampang tiap profil.

\section{STUDI PUSTAKA}

\section{A. Konstruksi Kapal}

Konstruksi kapal pada umumnya terdiri dari badan kapal dan bangunan atas. Pada bagian badan kapal terdiri dari konstruksi alas, lambung, dan satu atau beberapa geladak. Bangunan atas atau superstructure adalah bangunan tambahan 
yang terletak di bagian atas badan kapal. Panjang bangunan atas tergantung fungsi bangunan tersebut, pada umumnya hanya sebagian dari panjang geladak tapi dapat juga sepanjang geladak tersebut. Pada sebuah kapal pada umumnya terdapat geladak forecastle yang terletak di ujung haluan kapal, geladak poop yang terletak di buritan kapal dan beberapa superstructure diatas geladak poop.

Pada bagian geladak kapal terdapat lubang palkah atau hatch yang berfungsi untuk proses bongkar muat. Untuk melindungi muatan dalam kapal dari kemungkinan masuknya air, lubang palkah harus diberi penutup dan terdapat penambahan ketinggian dari geladak yang disebut ambang palkah.

Badan kapal dibagi oleh bidang-bidang konstruksi menjadi ruangan-ruangan terpisah. Penyekatan ruangan-ruangan terpisah berguna untuk meminimalisir dampak kebocoran, sehingga kapal diharapkan masih dapat terapung jika salah satu ruang terisi oleh air akibat kebocoran. Selain meminimalisir dampak kebocoran, pembagian ruangan juga berguna untuk mencegah penyebaran api akibat kebakaran. Bidang konstruksi yang membagi badan kapal pada arah melintang disebut sekat melintang (transverse bulkhead) dan arah memanjang sekat memanjang (longitudinal bulkhead).

Pada kapal general cargo pada umumnya membagi ruang muat menjadi beberapa bagian dengan sekat melintang, hal ini bertujuan untuk mengurangi kerusakan terhadap kapal maupun muatan apabila terjadi kebocoran atau kebakaran.

\section{B. Sistem Konstruksi Kapal}

Konstruksi kapal pada dasarnya terdiri atas komponenkomponen yang menopang kapal secara melintang dan memanjang. Terdapat tiga macam framing system atau sistem konstruksi kapal untuk merancang komponen-komponen tersebut menjadi suatu badan kapal. Ketiga sistem tersebut adalah:

\section{1) Sistem Konstruksi Memanjang}

Adalah konstruksi dimana kapal terdiri atas balok dan gading melintang yang berjauhan. Balok dan gading tersebut ditumpu oleh pembujur-pembujur yang berdekatan. Pada sistem ini komponen melintang dirancang saling berjauhan, tapi tetap bisa memberi kekuatan untuk menopang karena terbantu dari pembujur-pembujur yang saling berdekatan.

\section{2) Sistem Konstruksi Melintang}

Adalah konstruksi dimana beban yang bekerja pada konstruksi diterima oleh pelat kulit dan diuraikan pada hubungan-hubungan balok-balok memanjang dari kapal dengan pertolongan balok-balok yang melintangi kapal. Dalam hal ini sebagai tumpuan kaku untuk balok-balok melintang dasar (floor) ialah lambung kapal, dinding-dinding sekat memanjang, dan penumpu tengah (center girder). Beban konstruksi geladak dilanjutkan dengan pertolongan balok melintang dari rangka geladak (beam) ke hubungan kaku yaitu lambung kapal dan dinding sekat memanjang. Beban dari konstruksi lambung dilanjutkan ke geladak dan dasar kapal dengan pertolongan balok-balok melintang yaitu gadinggading (frame).

\section{3) Sistem Konstruksi Kombinasi}

Sistem konstruksi kombinasi adalah gabungan dari sistem konstruksi melintang dan sistem konstruksi memanjang. Penggunaan sistem konstruksi kombinasi disebabkan karena adanya kelebihan dan kekurangan dari masing-masing sistem konstruksi. Dalam sistem kombinasi ini, sistem rangka konstruksi memanjang dipakai pada geladak utama dan dasar kapal dimana letak konstruksi ini jauh dari sumbu netral penampang melintang kapal sehingga menerima beban lengkung yang besar.

\section{Perhitungan Konstruksi Midship Kapal}

Untuk menghitung konstruksi kapal diperlukan beban yang bekerja terlebih dahulu. Setelah dilakukan perhitungan beban, ketebalan pelat dapat ditentukan karena nilai beban diketahui. Dari nilai beban ditambah dengan titik berat dapat ditentukan nilai modulus untuk pemilihan konstruksi profil yang akan digunakan. Peraturan yang digunakan untuk melakukan perhitungan konstruksi pada midship kapal adalah peraturan Biro Klasifikasi Indonesia (BKI). Peraturan mengenai konstruksi kapal terdapat pada Volume II Rules for Hull. Untuk perhitungan beban terdapat dalam Section 4 Design Loads. Untuk perhitungan ketebalan pelat, terdapat pada Section 6 Shell Plating. Untuk menghitung nilai modulus minimum profil, pada konstruksi alas terdapat dalam Section 8 Bottom Structures. Untuk konstruksi lambung terdapat dalam Section 9 Framing System. Untuk konstruksi geladak terdapat dalam Section 10 Deck Beams and Supporting Deck Structures [3].

\section{Excel Visual Basic for Applications}

Excel VBA adalah nama dari bahasa pemrograman Microsoft Excel [4]. Sejak diterapkan pada tahun 1993, VBA meningkatkan kemampuan Excel untuk melakukan automatisasi di dalam Excel. Selain itu juga menambahkan fungsi-fungsi yang dapat didefinisikan oleh pengguna userdefined functions (UDF) untuk digunakan di dalam Excel. Dalam versi selanjutnya, Microsoft menambahkan sebuah integrated development environment (IDE) untuk bahasa VBA pada Excel, sehingga memudahkan pengguna untuk melakukan pembuatan program. Selain itu, Excel juga dapat merekam semua yang dilakukan oleh pengguna untuk menjadi macro, sehingga mampu melakukan otomatisasi beberapa tugas. VBA juga mengizinkan pembuatan form dan kontrol yang terdapat di dalam worksheet untuk dapat berkomunikasi dengan penggunanya. Pada versi selanjutnya menambahkan dukungan terhadap class module sehingga mengizinkan penggunaan teknik pemrograman berorientasi objek dalam VBA.

\section{E. Optimisasi}

Optimisasi adalah tindakan untuk mendapatkan nilai terbaik dalam suatu keadaan. Dalam mendesain, membangun dan memelihara suatu sistem, terdapat banyak pilihan teknologi dan metode pengelolaan yang akan digunakan. Tujuan utama dari semua pemilihan tersebut antara untuk meminimalkan upaya yang diperlukan atau untuk memaksimalkan manfaat yang diinginkan. Kedua tujuan ini dapat dibentuk menjadi 
sebuah fungsi dari variabel-variabel keputusan yang dipilih, sehingga optimisasi dapat didefinisikan sebagai proses mencari kondisi yang memberikan nilai maksimum atau minimum dari sebuah fungsi [4].

\section{F. Solver}

Solver adalah program tambahan (add-in) dalam Excel untuk menganalisa masalah yang rumit, termasuk skenario yang memiliki beberapa nilai sel yang berubah dan aturan tambahan dengan menggunakan pendekatan trial-and-error [5]. Solver digunakan untuk mendapatkan nilai optimal baik maksimum, minimum atau yang diinginkan pada suatu cell yang disebut objective cell. Untuk mengoptimasi objective cell diperlukan variabel terkait yang dapat diubah beserta batasanbatasan variabel. Solver akan menyesuaikan variabel yang dapat berubah dengan batasan yang telah ditentukan agar tercapai nilai objective cell yang diinginkan.

\section{METODOLOGI}

\section{A. Rangkaian Pengerjaan Perancangan Program}

Proses kerja perancangan aplikasi adalah sebagai berikut

1. Studi Literatur dan Pemeriksaan Kelengkapan Aplikasi

2. Merancang Rangkaian Alur Aplikasi

3. Merancang Database Profil L, T dan Bulb

4. Merancang Perhitungan dalam Sheet Excel

5. Merancang UserForm untuk Input Data Kapal

6. Penulisan Macro untuk Penggambaran pada AutoCAD

7. Penulisan Macro untuk Optimisasi

8. Perancangan UserForm untuk Rekapitulasi Hasil Perhitungan Aplikasi

9. Uji Coba Aplikasi

\section{B. Peralatan dan Perangkat Perancangan Aplikasi}

Dalam perancangan aplikasi pada studi ini, digunakan laptop dengan spesifikasi sebagai berikut:

1.Processor: AMD Quad-Core A8-4500M @ $1.90 \mathrm{GHz}$

2. RAM: 8 GB

Sedangkan untuk perangkat lunak yang digunakan adalah sebagai berikut:

1. Operating System: Windows 10 Home Single

Language 64-bit

2. Microsoft Excel 2016

3. Excel Visual Basic for Applications

4. Excel Solver

5. AutoCAD 2015 Student Edition

\section{Perhitungan Konstruksi Midship}

Peraturan mengenai konstruksi kapal terdapat pada Volume II Rules for Hull Biro Klasifikasi Indonesia. Untuk perhitungan beban terdapat dalam bab 4 . Untuk perhitungan ketebalan pelat terdapat pada bab 6. Untuk menghitung konstruksi terkait alas terdapat dalam bab 8. Untuk perhitungan terkait konstruksi lambung terdapat dalam bab 9 . Untuk perhitungan terkait konstruksi geladak terdapat dalam bab 10. Dari bab-bab tersebut hanya sebagian persamaan yang digunakan, karena aplikasi hanya menghitung untuk bagian midship.

\section{Pengunaan Solver untuk Optimisasi}

Untuk melakukan optimisasi diperlukan tiga tabel pemeriksaan modulus penampang profil, pertama adalah kondisi awal, kedua untuk optimisasi menggunakan solver dan terakhir untuk pembulatan ke angka lima diatas. Dengan ketiga tabel tersebut, dapat dijalankan solver dengan objective cell modulus penampang profil teroptimisasi, lebar face dan tinggi web teroptimisasi sebagai variabel dan metode yang digunakan GRG Nonlinear. Kemudian batasan-batasan yang berlaku terinci dalam tabel berikut.

Tabel 1

Batasan yang Berlaku untuk Optimisasi Profil

\begin{tabular}{ll}
\hline \multicolumn{2}{c}{ Batasan } \\
\hline W teroptimisasi & $\geq$ W perhitungan BKI \\
W teroptimisasi & $\leq$ W kondisi awal \\
Lebar face teroptimisasi & $\leq$ Lebar face kondisi awal \\
Tinggi web teroptimisasi & $\leq$ Tinggi web kondisi awal \\
\hline \hline
\end{tabular}

\section{PERANCANGAN}

Perancangan aplikasi ini secara umum dibagi menjadi 4 bagian yaitu, perancangan tampilan userform, perancangan sheet perhitungan, perancangan macro untuk penggambaran sketsa dan perancangan macro untuk optimisasi. Pembagian ini berdasarkan urutan proses kerja aplikasi dari mulai data dimasukkan pengguna hingga akhir ketika didapatkan hasil perhitungan dan optimisasi profil beserta pemeriksaan minimum midship section modulus.

\section{A. Perancangan Tampilan UserForm}

Pada perancangan aplikasi UserForm berguna untuk membuat user interface pemasukkan data kapal oleh pengguna. Aplikasi ini menggunakan dua UserForm, pertama SplashUserForm berfungsi untuk menampilkan splash screen untuk menampilkan informasi tentang aplikasi dan tombol perintah untuk melanjutkan ke form kedua.

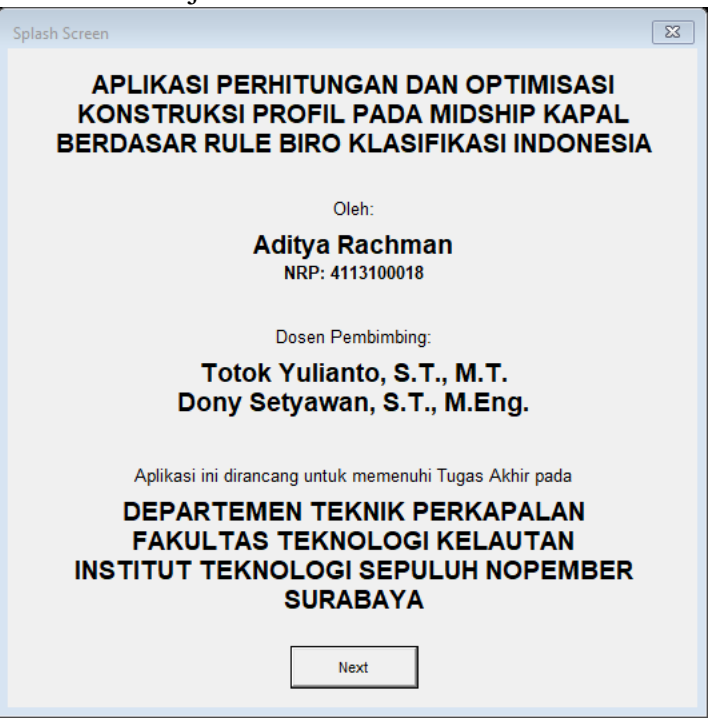

Gambar 1. Splash Screen

Halaman utama form kedua hanya berisi informasi dan tombol perintah Close untuk menutup form. Untuk memulai 
pemasukkan data dapat mengganti ke halaman pemasukkan data dengan menekan tulisan Main Dimension. Pembagian halaman ini merupakan hasil dari MultiPage.

Halaman Main Dimension terdapat textbox-textbox dan tombol opsi untuk data yang akan dimasukkan oleh pengguna. Data-data yang dimasukkan ke textbox pada umumnya berupa angka, oleh karena itu perlu dituliskan ketentuan-ketentuan tertentu sesuai data yang akan diinput. Begitu pula pada tombol perintah, jika terdapat kekurangan data dalam menjalankan perintah, maka akan tampil pesan error.

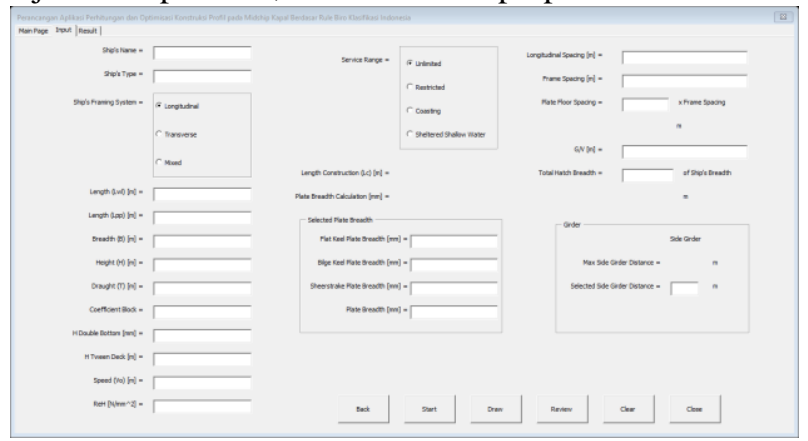

Gambar 2. Form Input Data Kapal

Untuk menampilkan hasil perhitungan serta optimisasi profil, dibuatkan lembar baru bernama Result. Lembar ini akan menampilkan profil serta pemeriksaan modulus minimal penampang midship saat kondisi perhitungan awal, peningkatan ukuran, optimisasi dan penggunaan profil bulb.

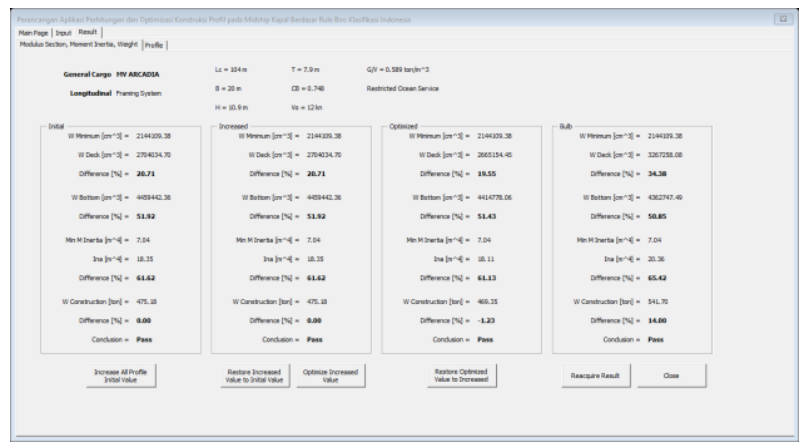

Gambar 3. Form Result Pemeriksaan Modulus Penampang Midship

\section{B. Perancangan Macro untuk Penggambaran Sketsa}

Pada tahap ini dirancang sheet berisi tabel perintah-perintah gambar yang akan dikirimkan ke AutoCAD. Perintah-perintah pada tabel telah diterapkan fungsi spesifik sesuai bagian yang akan digambar, sehingga tidak akan terjadi kesalahan seperti terdapat pembujur sisi pada ketinggian yang sama dengan tween deck dan kemungkinan lainnya.

\section{Perancangan Macro untuk Optimisasi}

Pada tahap ini perhitungan awal modulus penampang profil dan modulus penampang midship telah dilakukan. Kemudian hasil pemeriksaan batas minimal modulus penampang midship masih ada perbedaan sebesar lebih dari 20\%. Optimasi dilakukan dengan melakukan perubahan ukuran profil tanpa mengubah ketebalan, proses ini dilakukan dengan memanfaatkan solver pada excel. Proses optimisasi menggunakan solver berjalan lebih cepat jika dituliskan dalam kode VBA, sehingga tidak diperlukan pemasukkan objective cell, batasan-batasan secara satu-persatu pada tiap profil. Dari hasil profil yang teroptimisasi ini dilakukan pemeriksaan batas minimum modulus penampang midship kembali. Kemudian hasil ditampilkan pada form hasil.

\section{HASIL DAN PEMBAHASAN}

Pembahasan hasil dari perancangan aplikasi dilakukan dengan uji coba. Uji coba aplikasi membutuhkan data kapal untuk menjalankan perhitungan, data-data tersebut yaitu nama, jenis kapal, sistem konstruksi, ukuran utama kapal, service range kapal, tinggi double bottom, tinggi tween deck, jarak antar gading, jarak antar pembujur, jarak antar wrang pelat, $\mathrm{ReH}$ material, G/V muatan, lebar pelat yang digunakan, total lebar hatch dan jarak antar side girder.

Untuk menguji setiap fungsi aplikasi, maka pengujian dilakukan dengan tiga data kapal. Pada data kapal pertama akan menghasilkan nilai modulus penampang midship yang tidak memenuhi batas minimal, Sehingga akan dilakukan peningkatan ukuran profil. Sedangkan pada data kapal kedua dan ketiga akan memenuhi batas minimal modulus penampang midship dan dapat dilakukan optimisasi ukuran profil. Untuk data kapal pertama terinci dalam tabel dibawah.

Tabel 2

Data Kapal Pertama

\begin{tabular}{|c|c|c|c|}
\hline Ship's & MV & "H Tween Deck & $6.7 \mathrm{~m}$ \\
\hline Name & ARCADIA & & \\
\hline Ship's & General & Longitudinal & $0.6 \mathrm{~m}$ \\
\hline Type & Cargo & Spacing & \\
\hline $\begin{array}{r}\text { Framing } \\
\text { System }\end{array}$ & Longitudinal & Frame Spacing & $0.6 \mathrm{~m}$ \\
\hline$L w l$ & $134.78 \mathrm{~m}$ & Floor Spacing & $\begin{array}{l}4 \mathrm{x} \text { frame } \\
\text { spacing }\end{array}$ \\
\hline Lpp & $129.6 \mathrm{~m}$ & $\mathrm{ReH}$ & $235 \mathrm{~N} / \mathrm{mm}^{2}$ \\
\hline Breadth & $20 \mathrm{~m}$ & Payload G/V & 0.589 \\
\hline Height & $10.9 \mathrm{~m}$ & Keel Breadth & $1800 \mathrm{~mm}$ \\
\hline Draught & $7.9 \mathrm{~m}$ & Bilge Keel B & $1800 \mathrm{~mm}$ \\
\hline$C_{B}$ & 0.748 & Sheerstrake & $1500 \mathrm{~mm}$ \\
\hline$V s$ & $12 \mathrm{kn}$ & Plate Breadth & $1800 \mathrm{~mm}$ \\
\hline $\begin{array}{c}\text { Service } \\
\text { Range }\end{array}$ & Restricted & $\begin{array}{r}\text { Total Hatch } \\
\text { Breadth }\end{array}$ & $\begin{array}{l}0.4 \text { of Ship's } \\
\text { Breadth }\end{array}$ \\
\hline$H_{D B}$ & $1300 \mathrm{~mm}$ & $\begin{array}{r}\text { Side Girder } \\
\text { Distance }\end{array}$ & $3.6 \mathrm{~m}$ \\
\hline
\end{tabular}

Dari data kapal pertama, didapatkan hasil perhitungan oleh aplikasi yang ditampilkan dalam tabel-tabel berikut.

$$
\text { Tabel } 3
$$

Hasil Kondisi Perhitungan Awal

\begin{tabular}{rrl}
\hline \hline \multicolumn{3}{c}{ Initial Condition } \\
\hline & 3545698.84 & \\
$\mathrm{~W}_{\text {min }}=$ & 6 & $\mathrm{~cm}^{3}$ \\
& 2911547.08 & \\
$\mathrm{~W}_{\text {deck }}=$ & 6 & $\mathrm{~cm}^{3}$ \\
Difference $=$ & -21.78 & $\%$ \\
$\mathrm{~W}_{\text {bot }}=$ & 4679642.76 & $\mathrm{~cm}^{3}$ \\
\hline \hline
\end{tabular}




\begin{tabular}{rrl}
\hline \hline & 4 & \\
Difference $=$ & 24.23 & $\%$ \\
$\mathrm{I}_{\mathrm{y}}=$ & 14.511 & $\mathrm{~m}^{4}$ \\
$\mathrm{I}_{\mathrm{NA}}=$ & 19.564 & $\mathrm{~m}^{4}$ \\
Difference $=$ & 25.83 & $\%$ \\
$\mathrm{~W}=$ & 625.538 & ton \\
Difference $=$ & 0.00 & $\%$ \\
Conclusion & Rejected & \\
\hline \hline
\end{tabular}

Hasil dari perhitungan modulus penampang midship profil yang telah ditingkatkan ukurannya adalah sebagai berikut.

$$
\text { Tabel } 4
$$

Hasil Kondisi Ukuran Ditingkatkan

\begin{tabular}{|c|c|c|}
\hline \multicolumn{3}{|c|}{ Increased Condition } \\
\hline \multirow{3}{*}{$\mathrm{W}_{\min }=$} & 3545698.84 & \\
\hline & 6 & $\mathrm{~cm}^{3}$ \\
\hline & 3593258.73 & $\mathrm{~cm}^{3}$ \\
\hline $\mathrm{W}_{\text {deck }}=$ & 7 & $\mathrm{~cm}^{2}$ \\
\hline Difference $=$ & 1.32 & $\%$ \\
\hline & 5646534.09 & $\mathrm{~cm}^{3}$ \\
\hline $\mathrm{W}_{\mathrm{bot}}=$ & 8 & $\mathrm{~cm}^{-}$ \\
\hline Difference $=$ & 37.21 & $\%$ \\
\hline $\mathrm{I}_{\mathrm{y}}=$ & 14.511 & $\mathrm{~m}^{4}$ \\
\hline $\mathrm{I}_{\mathrm{NA}}=$ & 23.935 & $\mathrm{~m}^{4}$ \\
\hline Difference $=$ & 39.37 & $\%$ \\
\hline $\mathrm{W}=$ & 763.939 & ton \\
\hline Difference $=$ & 22.13 & $\%$ \\
\hline Conclusion & Pass & \\
\hline
\end{tabular}

Dari hasil perhitungan modulus penampang menggunakan profil bulb didapatkan hasil sebagai berikut.

$$
\text { Tabel } 5
$$

\begin{tabular}{|c|c|c|}
\hline \multicolumn{3}{|c|}{ Bulb Condition } \\
\hline & 3545698.84 & $\mathrm{~cm}^{3}$ \\
\hline $\mathrm{W}_{\min }=$ & 6 & $\mathrm{~cm}^{2}$ \\
\hline & 3474762.60 & $\mathrm{~cm}^{3}$ \\
\hline $\mathrm{W}_{\mathrm{deck}}=$ & 6 & $\mathrm{~cm}^{2}$ \\
\hline Difference $=$ & -2.04 & $\%$ \\
\hline & 4580593.15 & $\mathrm{~cm}^{3}$ \\
\hline $\mathrm{W}_{\text {bot }}=$ & 2 & $\mathrm{~cm}^{-}$ \\
\hline Difference $=$ & 22.59 & $\%$ \\
\hline $\mathrm{I}_{\mathrm{y}}=$ & 14.511 & $\mathrm{~cm}^{4}$ \\
\hline $\mathrm{I}_{\mathrm{NA}}=$ & 21.537 & $\mathrm{~cm}^{4}$ \\
\hline Difference $=$ & 32.62 & $\%$ \\
\hline $\mathrm{W}=$ & 708.841 & ton \\
\hline Difference = & 13.32 & $\%$ \\
\hline Conclusion & Rejected & \\
\hline
\end{tabular}

Hasil Kondisi Penggunaan Profil Bulb

Data kapal kedua merupakan modifikasi dari data kapal pertama. Berikut adalah data kapal kedua.

$$
\text { Tabel } 6
$$

\begin{tabular}{|c|c|c|c|}
\hline$L p p$ & $104 \mathrm{~m}$ & $\mathrm{ReH}$ & $\begin{array}{l}\text { spacing } \\
235 \mathrm{~N} / \mathrm{mm}^{2}\end{array}$ \\
\hline Breadth & $20 \mathrm{~m}$ & Payload $G / V$ & 0.589 \\
\hline Height & $10.9 \mathrm{~m}$ & Keel Breadth & $1800 \mathrm{~mm}$ \\
\hline Draught & $7.9 \mathrm{~m}$ & Bilge Keel B & $1800 \mathrm{~mm}$ \\
\hline$C_{B}$ & 0.748 & Sheerstrake & $1500 \mathrm{~mm}$ \\
\hline$V s$ & $12 \mathrm{kn}$ & Plate Breadth & $1800 \mathrm{~mm}$ \\
\hline $\begin{array}{c}\text { Service } \\
\text { Range }\end{array}$ & Restricted & $\begin{array}{r}\text { Total Hatch } \\
\text { Breadth }\end{array}$ & $\begin{array}{l}0.4 \text { of Ship's } \\
\text { Breadth }\end{array}$ \\
\hline$H_{D B}$ & $1300 \mathrm{~mm}$ & $\begin{array}{r}\text { Side Girder } \\
\text { Distance }\end{array}$ & $3.6 \mathrm{~m}$ \\
\hline
\end{tabular}

Data Kapal Kedua

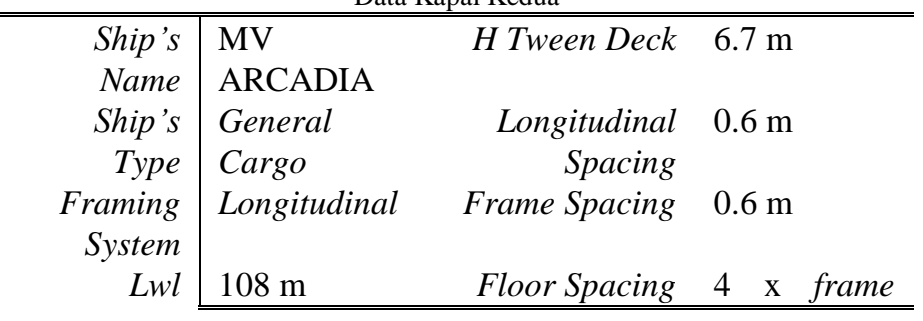

Modifikasi dilakukan dengan mengurangi ukuran Lwl dan Lpp dengan tujuan mengurangi nilai minimum midship section modulus. Berikut adalah hasil perhitungan awal.

$$
\text { Tabel } 7
$$

Hasil Kondisi Perhitungan Awal

\begin{tabular}{rrl}
\multicolumn{3}{c}{ Hasil Kondisi Perhitungan Awal } \\
\hline \hline \multicolumn{3}{c}{ Initial Condition } \\
$\mathrm{W}_{\text {min }}=$ & 2144109.37 & $\mathrm{~cm}^{3}$ \\
& 9 & \\
$\mathrm{~W}_{\text {deck }}=$ & 704034.69 & $\mathrm{~cm}^{3}$ \\
Difference $=$ & 20.71 & $\%$ \\
& 4459442.35 & $\mathrm{~cm}^{3}$ \\
$\mathrm{~W}_{\mathrm{bot}}=$ & 6 & \\
Difference $=$ & 51.92 & $\%$ \\
$\mathrm{I}_{\mathrm{y}}=$ & 7.042 & $\mathrm{~m}^{4}$ \\
$\mathrm{I}_{\mathrm{NA}}=$ & 18.348 & $\mathrm{~m}^{4}$ \\
Difference $=$ & 61.62 & $\%$ \\
$\mathrm{~W}=$ & 475.181 & ton \\
Difference $=$ & 0 & $\%$ \\
Conclusion & Pass & \\
\hline \hline
\end{tabular}

\begin{tabular}{|c|c|c|}
\hline \multicolumn{3}{|c|}{ Optimized Condition } \\
\hline & 2144109.37 & \\
\hline $\mathrm{W}_{\min }=$ & 9 & $\mathrm{~cm}^{-}$ \\
\hline & 2665154.45 & $\mathrm{~cm}^{3}$ \\
\hline $\mathrm{W}_{\text {deck }}=$ & 3 & $\mathrm{cmI}$ \\
\hline Difference $=$ & 19.55 & $\%$ \\
\hline & 4414778.06 & $\mathrm{~cm}^{3}$ \\
\hline $\mathrm{W}_{\mathrm{bot}}=$ & 4 & $\mathrm{~cm}^{2}$ \\
\hline Difference $=$ & 51.43 & $\%$ \\
\hline $\mathrm{I}_{\mathrm{y}}=$ & 7.042 & $\mathrm{~m}^{4}$ \\
\hline $\mathrm{I}_{\mathrm{NA}}=$ & 18.115 & $\mathrm{~m}^{4}$ \\
\hline Difference $=$ & 61.13 & $\%$ \\
\hline $\mathrm{W}=$ & 469.355 & ton \\
\hline Difference $=$ & -1.2262 & $\%$ \\
\hline Conclusion & Pass & \\
\hline
\end{tabular}

Hasil dari perhitungan modulus penampang midship profil teroptimasi adalah sebagai berikut.

$$
\text { Tabel } 8
$$

Dari hasil perhitungan modulus penampang menggunakan profil bulb didapatkan hasil sebagai berikut.

$$
\text { Tabel } 9
$$

Hasil Kondisi Penggunaan Profil Bulb

\begin{tabular}{rrl}
\hline \hline \multicolumn{3}{c}{ Bulb Condition } \\
\hline $\mathrm{W}_{\min }=$ & 2144109.38 & $\mathrm{~cm}^{3}$ \\
$\mathrm{~W}_{\text {deck }}=$ & 3267258.08 & $\mathrm{~cm}^{3}$ \\
Difference $=$ & 34.38 & $\%$ \\
\hline \hline
\end{tabular}




\begin{tabular}{rrl}
\hline \hline $\mathrm{W}_{\mathrm{bot}}=$ & 4362747.49 & $\mathrm{~cm}^{3}$ \\
Difference $=$ & 50.85 & $\%$ \\
$\mathrm{I}_{\mathrm{y}}=$ & 7.04 & $\mathrm{~cm}^{4}$ \\
$\mathrm{I}_{\mathrm{NA}}=$ & 20.36 & $\mathrm{~cm}^{4}$ \\
Difference $=$ & 65.42 & $\%$ \\
$\mathrm{~W}=$ & 541.70 & ton \\
Difference $=$ & 14.00 & $\%$ \\
Conclusion & Pass & \\
\hline \hline
\end{tabular}

Data pada kapal ketiga merupakan kapal yang berbeda dari kapal pertama dan kedua. Seperti pada data kapal kedua, akan dihasilkan modulus penampang midship minimum. Berikut adalah tabel data kapal ketiga.

Tabel 10

Data Kapal Ketiga

\begin{tabular}{|c|c|c|c|}
\hline $\begin{array}{l}\text { Ship's } \\
\text { Name }\end{array}$ & MV AM & H Tween Deck & $4.5 \mathrm{~m}$ \\
\hline Ship's & General & Longitudinal & $0.6 \mathrm{~m}$ \\
\hline Type & Cargo & Spacing & \\
\hline $\begin{array}{r}\text { Framing } \\
\text { System }\end{array}$ & Longitudinal & Frame Spacing & $0.6 \mathrm{~m}$ \\
\hline$L w l$ & $94 \mathrm{~m}$ & Floor Spacing & $\begin{array}{l}5 \mathrm{x} \text { frame } \\
\text { spacing }\end{array}$ \\
\hline$L p p$ & $90 \mathrm{~m}$ & $\mathrm{ReH}$ & $235 \mathrm{~N} / \mathrm{mm} 2$ \\
\hline Breadth & $16 \mathrm{~m}$ & Payload $G / V$ & 0.807 \\
\hline Height & $8.1 \mathrm{~m}$ & Keel Breadth & $1800 \mathrm{~mm}$ \\
\hline Draught & $6.6 \mathrm{~m}$ & Bilge Keel B & $1800 \mathrm{~mm}$ \\
\hline$C_{B}$ & 0.747 & Sheerstrake & $1500 \mathrm{~mm}$ \\
\hline$V s$ & $12 \mathrm{kn}$ & Plate Breadth & $1800 \mathrm{~mm}$ \\
\hline Service & Restricted & Total Hatch & 0.4 of Ship's \\
\hline Range & & Breadth & Breadth \\
\hline$H_{D B}$ & $1100 \mathrm{~mm}$ & $\begin{array}{r}\text { Side Girder } \\
\text { Distance }\end{array}$ & $3 \mathrm{~m}$ \\
\hline
\end{tabular}

Dari data kapal ketiga yang digunakan, didapatkan hasil perhitungan oleh aplikasi yang ditampilkan dalam tabel-tabel dibawah. Untuk hasil perhitungan awal adalah sebagai berikut. Tabel 11

Hasil Kondisi Perhitungan Awal

\begin{tabular}{rrl}
\hline \hline \multicolumn{3}{c}{ Initial Condition } \\
& 1243143.61 & \\
$\mathrm{~W}_{\min }=$ & 3 & $\mathrm{~cm}^{3}$ \\
& 1587574.80 & \\
$\mathrm{~W}_{\mathrm{deck}}=$ & 1 & $\mathrm{~cm}^{3}$ \\
Difference $=$ & 21.70 & $\%$ \\
& 2590092.13 & \\
$\mathrm{~W}_{\mathrm{bot}}=$ & 9 & $\mathrm{~cm}^{3}$ \\
Difference $=$ & 52.00 & $\%$ \\
$\mathrm{I}_{\mathrm{y}}=$ & 3.543 & $\mathrm{~m}^{4}$ \\
$\mathrm{I}_{\mathrm{NA}}=$ & 7.973 & $\mathrm{~m}^{4}$ \\
Difference $=$ & 55.57 & $\%$ \\
$\mathrm{~W}=$ & 328.053 & ton \\
Difference $=$ & 0.00 & $\%$ \\
Conclusion & Pass & \\
\hline \hline
\end{tabular}

Hasil dari perhitungan modulus penampang midship profil teroptimasi adalah sebagai berikut.
Tabel 12

Hasil Kondisi Teroptimisasi

\begin{tabular}{|c|c|c|}
\hline \multicolumn{3}{|c|}{ Optimized Condition } \\
\hline & 1243143.61 & $\mathrm{~cm}^{3}$ \\
\hline $\mathrm{W}_{\min }=$ & 3 & $\mathrm{~cm}^{\prime}$ \\
\hline & 1561201.06 & $\mathrm{~cm}^{3}$ \\
\hline $\mathrm{W}_{\text {deck }}=$ & 4 & $\mathrm{~cm}^{-}$ \\
\hline Difference $=$ & 20.37 & $\%$ \\
\hline & 2553966.12 & $\mathrm{~cm}^{3}$ \\
\hline $\mathrm{W}_{\text {bot }}=$ & 6 & \\
\hline Difference $=$ & 51.32 & $\%$ \\
\hline $\mathrm{I}_{\mathrm{y}}=$ & 3.543 & $\mathrm{~m}^{4}$ \\
\hline $\mathrm{I}_{\mathrm{NA}}=$ & 7.848 & $\mathrm{~m}^{4}$ \\
\hline Difference $=$ & 54.86 & $\%$ \\
\hline $\mathrm{W}=$ & 322.967 & ton \\
\hline Difference $=$ & -1.55 & $\%$ \\
\hline Conclusion & Pass & \\
\hline
\end{tabular}

Dari hasil perhitungan modulus penampang menggunakan profil bulb didapatkan hasil sebagai berikut.

Tabel 13

Hasil Kondisi Penggunaan Profil Bulb

\begin{tabular}{|c|c|c|}
\hline \multicolumn{3}{|c|}{ Bulb Condition } \\
\hline & 1243143.61 & \\
\hline $\mathrm{W}_{\text {min }}=$ & 3 & $\mathrm{~cm}^{3}$ \\
\hline & 1975864.71 & $\mathrm{~cm}^{3}$ \\
\hline $\mathrm{W}_{\text {deck }}=$ & 5 & $\mathrm{~cm}^{\prime}$ \\
\hline Difference $=$ & 37.08 & $\%$ \\
\hline & 2284562.26 & $\mathrm{~cm}^{3}$ \\
\hline $\mathrm{W}_{\mathrm{bot}}=$ & 8 & $\mathrm{~cm}^{\prime}$ \\
\hline Difference $=$ & 45.59 & $\%$ \\
\hline $\mathrm{I}_{\mathrm{y}}=$ & 3.543 & $\mathrm{~cm}^{4}$ \\
\hline $\mathrm{I}_{\mathrm{NA}}=$ & 8.582 & $\mathrm{~cm}^{4}$ \\
\hline Difference $=$ & 58.72 & $\%$ \\
\hline $\mathrm{W}=$ & 382.378 & ton \\
\hline Difference $=$ & 16.56 & $\%$ \\
\hline Conclusion & Pass & \\
\hline
\end{tabular}

\section{KESIMPULAN DAN SARAN}

\section{A. Kesimpulan}

Dari hasil dan pembahasan uji coba aplikasi didapatkan beberapa kesimpulan sebagai berikut:

1) Aplikasi perhitungan dan optimisasi profil dapat diciptakan menggunakan Microsoft Excel dengan memanfaatkan bahasa pemrograman Visual Basic for Applications untuk otomatisasi dan aplikasi Solver untuk optimisasi.

2) Aplikasi dapat melakukan peningkatan ukuran profilprofil di midship sehingga modulus penampang midship terhadap geladak dari kondisi tidak lolos pada perbedaan $21.78 \%$ menjadi $+1.32 \%$ terhadap batas minimum.

3) Aplikasi dapat melakukan optimisasi pada profil-profil di midship sehingga perbedaan modulus penampang midship terhadap geladak dengan batas minimum BKI dari $20.71 \%$ menjadi $19.55 \%$. Dari $51.92 \%$ menjadi $51.43 \%$ untuk modulus penampang terhadap alas. 


\section{B. Saran}

Dalam pengerjaan Studi ini terdapat beberapa saran mengenai pengembangan lanjut yang dapat dilakukan dari aplikasi ini, yaitu:

1) Membuat proses untuk optimisasi profil Bulb, karena pada studi ini baru sebatas pengambilan data.

2) Memperluas lingkup perhitungan hingga pengaruh ke kekuatan memanjang kapal.

\section{UCAPAN TERIMA KASIH}

Penulis A.R. mengucapkan terima kasih kepada Bapak Totok Yulianto, S.T.,M.T. dan Bapak Dony Setyawan, S.T.,
M.Eng. selaku pembimbing penulis dalam studi ini.

\section{DAFTAR PUSTAKA}

[1] H. M. Fitri, "Perancangan Perangkat Lunak Sebagai Media Pembelajaran Interaktif Konstruksi Midship Kapal Tanker yang Sesuai Dengan Peraturan Biro Klasifikasi Indonesia (BKI)," Institut Teknologi Sepuluh Nopember, 2016.

[2] J. K. Dewanti, "Perhitungan Konstruksi pada Engine Room Kapal Tanker Menggunakan Bahasa Pemrograman Sesuai Peraturan Biro Klasifikasi Indonesia," Institut Teknologi Sepuluh Nopember, 2016.

[3] B. K. Indonesia, Volume II Rules for Hull. 2017.

[4] C. Lee, Buku Pintar Macro Ms. Excel. Jakarta: MediaKita, 2015.

[5] S. S. Rao, Engineering Optimization Theory and Practice. New Jersey: John Wiley \& Sons Inc, 2009. 